\title{
Why current assessments of 'future efforts' are no basis for establishing policies on material use-a response to research on ore grades
}

\author{
Magnus Ericsson $^{1}$ (D) $\cdot$ Johannes Drielsma ${ }^{2} \cdot$ David Humphreys $^{3} \cdot$ Per Storm $^{4} \cdot$ Pär Weihed $^{5}$
}

Received: 27 July 2018 / Accepted: 14 February 2019 / Published online: 25 March 2019

(C) The Author(s) 2019

\begin{abstract}
The concept of declining availability due to declining primary resource quality has been investigated for various resource categories to try to determine the effort needed in future to either extract the resource or to treat it for intended use. The concept of 'future efforts' due to declining primary resource quality is explored by Vieira et al. (2016, 2017). They suggest that a specific burden associated with the production of each primary material should be taken into account and that this can be done by studying the costs of production or ore requirements of the material and by projecting forward likely costs into the future. For the purpose of the analysis, they employ mine cost data for 2000-2013 and reserve data published by the US Geological Survey. We will argue below that this approach is not correct and, with this comment, we wish to make it clear that — contrary to what is suggested in much of the Life Cycle Assessment literature- the future efforts concept is not an established rule of natural resource extraction. For mineral resources, it is quite impossible to proceed with extraction in the ordered way that this approach suggests because nobody has a comprehensive view of the entire natural resource. Secondly, there is no evidence available to support the idea that extracting a mineral resource today causes a decrease in availability of that mineral tomorrow. On the contrary, the weight of evidence suggests that where declines in ore grades have been observed, they are overwhelmingly due to technology development in response to high demand and have been accompanied by increased mining efficiency and increased availability of the resource to successive generations. Grade is a rather arbitrary measure since the grade of mined ore ultimately has to do with the relationship of costs and revenues. It is not only the technology employed which matters but also how smartly this technology is applied. Thirdly, the future efforts approach entirely overlooks the potential availability of mineral materials from secondary (scrap) sources, sources which are expected to become increasingly important to mineral supply in the future. Our conclusion from the discussion is that we as humans have been able to economically access ever-increasing amounts of material from often lower and lower-grade sources. What is impossible to conclude from this is that the environment no longer contains any of the higher-grade sources. In fact, all the available evidence suggests that higher-grade deposits are still out there. We remain critical optimists.
\end{abstract}

Keywords Future efforts · Ore grade · Declining availability · Life Cycle Assessment · "Type 3" · Hotelling · Surplus cost

Magnus Ericsson

magnus@gladtjarnen.se

1 Luleå University of Technology Economics Unit, 971 87 Luleå, Sweden

2 European Association of Mining Industries, Metal Ores and Industrial Minerals, Avenue de Broqueville/Broquevillelaan 12, 1150 Brussels, Belgium

3 CEPMLP, Dundee University, Dundee, UK

4 EIT Raw Materials North AB, Luleå, Sweden

5 Luleå University of Technology, 97187 Luleå, Sweden

\section{Introduction}

The concept of declining availability due to declining primary resource quality has been investigated for various resource categories (Dewulf et al. 2015) to try to determine the effort needed in future to either extract the resource (in the case of minerals/metals and fossil fuels) or to treat it for intended use (in the case, for example, of water and soil). This concept has been picked up by the field of Life Cycle Assessment, which seeks to quantify and aggregate environmental impacts potentially arising from the complete set of processes occurring over the whole life-cycle of a product or service. 
Sonderegger et al. (2017) describe 'Type 3'or 'future efforts' methods of life-cycle impact assessment as a means of incorporating impacts on scarcity of mineral resources into life cycle assessments (LCA). The relevant paragraphs are not easy to follow but, stripped to its essentials, the argument appears to be this: Mining imposes a burden on the earth, a burden the authors define as future efforts. This burden is increasing with time, and even if it is not, it might be reasonable to assume that it is for the purpose of comparing potential impacts of resource use 'on a common scale' in LCA.

For example, the concept of future efforts due to declining primary resource quality is explored by Vieira et al. (2016) and Vieira et al. (2017) in their work. Vieira et al. (2016) relate current resource consumption to potential consequences for future extraction of resources-quantified in terms of a 'surplus cost potential'. Vieira et al. (2017) quantify the same potential consequences in terms of a 'surplus ore potential'. They suggest that a specific burden associated with the production of each primary material should be taken into account and that this can be done by studying the costs or ore requirements of production of the material and by projecting forward likely costs or ore requirements into the future. As the authors put it, their goal is 'to assess the increase in scarcity of resources extracted' for use in the product system under study. For the purpose of the analysis, they employ mine cost data for 2000-2013 and reserves data published by the US Geological Survey.

In so doing, they make a number of critical assumptions:

- That mines with lower operating costs are exploited first,

- That in the long run, the effort to extract resources will increase due to declining quality of deposits,
- That ore grades tend to decrease with the increase of metal extraction and that ore grades mined in the future will therefore be lower, and/or

- That increased primary metal extraction results in an increase in mining and milling costs and energy consumption for subsequent (future) extraction.

We will argue that this approach is incorrect, and with this Comment, we wish to make it clear that - contrary to what is suggested in much of the Life Cycle Assessment literature (Vieira et al. 2012; Goedkoop et al. 2013; Swart and Dewulf 2013; Sonderegger et al. 2017) - the future efforts concept is not an established rule of natural resource extraction. For mineral resources, it is quite impossible to proceed with extraction in the ordered way that this approach suggests because there is no comprehensive view of the entire natural resource. Secondly, there is no evidence available to support the idea that extracting a mineral resource today causes a decrease in availability of that mineral tomorrow. On the contrary, the weight of evidence suggests that where declines in ore grades have been observed they are overwhelmingly due to technology development in response to high demand and have been accompanied by increased mining efficiency and increased availability of the resource to successive generations. Grade is a rather arbitrary measure since the grade of mined ore ultimately has to do with the relationship of costs and revenues. It is not only the technology employed, which matters, but also how smartly this technology is applied. The Swedish copper mine Aitik, where mine life has been continuously extended over a long period through the discovery of new reserves, provides an interesting and persuasive clarifying case study. See Fig. 1. Thirdly, the future efforts approach entirely overlooks the potential availability of mineral
Fig. 1 Unit on the $Y$-axis kt (thousand tonne). Source: Boliden (Boliden, personal communication with Gunnar Agmalm, 2010)

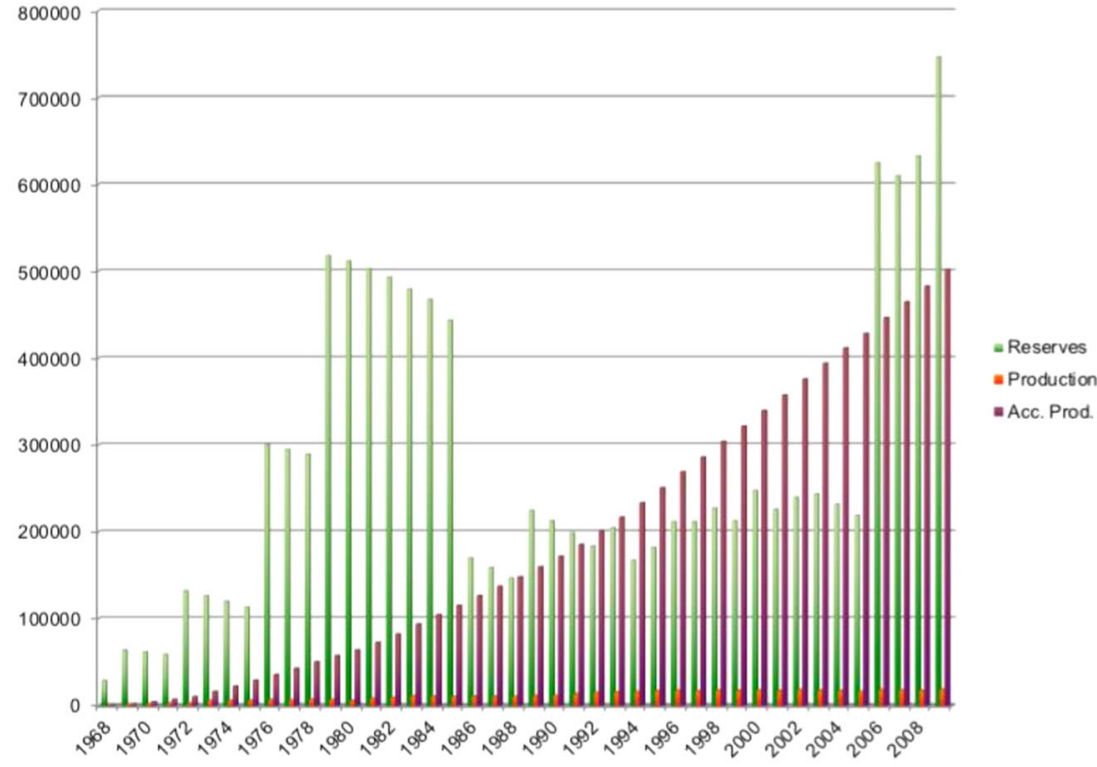


materials from secondary (scrap) sources, sources which are expected to become increasingly important to mineral supply in the future.

Our paper starts by looking at the theory of Harold Hotelling, the concept of 'ore', the development of ore grades, and the relation between ore grades and environmental impact. Our critical assessment of the concept of future efforts goes into details such as examples of ore grade declines and increases, exploration performance, supply responses and production costs, with particular reference to Vieira et al. (2016) and Vieira et al. (2017) as cases in point. Our data only deal with metallic ores, but there is nothing to suggest that the conclusions are not valid also for non-metallic ores.

\section{The roots of the problem}

\section{Hotelling}

Modern resource theory can be traced back to a seminal paper published in 1931 by the US economist Harold Hotelling (Hotelling 1931). In this paper, Hotelling investigated the economic and geological factors that should guide decisionmaking in relation to the optimal rate for mineral extraction. Although Hotelling's analysis focused on individual mines and the depletion of those mines, it is clear from the paper that the thinking was intended to have wider implications and there is an explicit assumption that the best resources are exploited first. There is also a strong inference that as costs will rise at a mine as ores deplete so across the industry as a whole costs can be expected to rise over time, and with them prices. While undoubtedly a major contribution to resource analysis, Hotelling's assumption that the best deposits will be worked first is flawed in as far as the best deposits are not necessarily known, so the most that can be claimed is that the best discovered resources are exploited first. ${ }^{1}$

Viera et al. $(2016,2017)$ and others (see Annex) appear to follow Hotelling in their conviction that, broadly speaking, society will use its best resources first and that the cost of production must rise as the quality of the remaining resources deteriorates and the economic cost of recovery (burden on the earth) rises. They provide a 'visualisation' of this process whereby the unit cost of producing copper rises as the tonnage of copper metal extracted increases. Unfortunately, in advancing their proposition, these authors ignore a large amount of historical evidence and economic research which has accumulated over the years since Hotelling wrote his paper.

\footnotetext{
${ }^{1}$ Provided the prevailing political situation permits mining investments. https://www.unenvironment.org/resources/report/environmental-risks-andchallenges-anthropogenic-metals-flows-and-cycles
}

Wellmer and Scholz (2017) provide a short history of similar misunderstandings, as well as fallacies surrounding the Hubbert curve (Hubbert 1956), the inverted U-shaped production curve of a commodity, which is often used as the basis for claims that every peak in production is caused by geological constraints.

Successive researchers have failed to find clear evidence that the cost of extracting mineral resources increases over time and indeed many have concluded quite the opposite, namely that cost of production of many minerals has actually declined. ${ }^{2}$

The reason for this is that the discoveries of new ore bodies through exploration and improvements in recovery and processing technologies have enabled the mining industry to offset the effects of mineral depletion by increases in productivity. It may also be the case that, for reason of ignorance about what is actually available, best resources do not actually always get used first. Admittedly, one cannot presume that this pattern will persist indefinitely, but, by the same token, one cannot reasonably presume that it will not persist for as long as human beings require mineral raw materials.

\section{Life cycle assessment and environmental mechanisms of impact}

\section{Ore grade as a proxy for environmental impacts}

One of the foundations of the Type 3 (future efforts) LCIA methods described by Sonderegger et al. (2017) is that there is assumed to be a linear relationship between quantities of resources extracted and irreversible environmental impact (e.g. Bringezu 2015). This assumption is premised on the belief that extracted quantities have to increase both because of increasing demand for the end products and because of decreasing ore grades and hence increasing volumes of ore will be mined and waste rock produced. The International Organisation for Standardisation (ISO) standard 14044 (ISO 140442006 , p. 19) explains that LCA is intended to calculate environmentally relevant impacts by associating them with distinct identifiable environmental mechanisms. But, is there a distinctly identifiable environmental mechanism which can

\footnotetext{
${ }^{2}$ For example, Barnett and Morse (1963), Scarcity and Growth: The Economics of Natural Resource Availability, Baltimore: Johns Hopkins University Press for Resources for the Future; Barnett (1979), 'Scarcity and Growth revisited', In Scarcity and Growth Reconsidered, edited by V.K. Smith. Baltimore: Johns Hopkins University Press for Resources for the Future, pp.: 163-217; Crowson (2003), 'Mine Size and the Structure of Costs', Resources Policy, Vol. 29 (1-2), pp.: 15-36; Howie (2002), 'A Study of Mineral: Analysing Long Term Behaviour and Testing for NonCompetitive Markets', Unpublished PhD dissertation, Colorado School of Mines, Golden, CO.; Manthy (1978), Natural Resource Commodities: A Century of Statistics, Resources for the Future, U.S.A.; Nordhaus (1974), 'Resources as a Constraint on Growth', American Economic Review, Vol. 64, No. 1, pp.: 22-26.
} 
be applied in this context? Understanding when ore grade decline does occur and over what time span is difficult, many other geological and management factors-ranging from the amount of overburden requiring to be removed, the nature of the mineralisation and the level of impurities acceptable to customers - determine waste volumes and associated environmental impacts. It is likely impossible to find some kind of immutable law or relationship between present-day extraction and future condition of the resource - as is found in physics, biology, or chemistry (Northey et al. 2018).

\section{Production costs as a measure of impacts}

The paper 'Surplus cost potential as a life cycle impact indicator for metal extraction' (Vieira et al. 2016) (see also Vieira et al. 2017) is one recent attempt to develop a future efforts method to find a measure of a metal's relative scarcity. The idea is to use projected increases in the average cost of recovery of the metal studied. The authors also claim that the method might be used as a basis for policy formulation.

For a number of reasons discussed below, we are convinced that this approach is not a passable route to understand the problems outlined nor a credible basis for policy formulation. There are several reasons in the real world why there is no simple relationship between what is discovered, what is mined and what is ultimately available (or depleted). To make such an assessment would require an all-encompassing knowledge of mineral deposits in the world, a level of knowledge that is, both from a practical and philosophical point of view, not possible to attain.

As Vieira et al. (2016) themselves indicate, the method has serious limitations, but the paper's conclusions suggest that the authors believe that these limitations can either be overcome or ignored. We want to point to a number of weaknesses in the method proposed and the data used in the study. These shortcomings are in our view so serious that it is not possible to use the results of the study to obtain useful and/or accurate data on scarcity of metals for use in an LCIA. ${ }^{3}$

There is no scientific way of predicting how metal mining costs are going to develop in the future. Vieira et al. (2016) simply assume that costs are going to increase based on evidence from the period between 2000 and 2013. If a more longterm approach is taken, the cost of production rather seems more likely to have been trending downwards than upwards (Barnett and Morse 1963; Tilton 2003; Tilton et al. 2018). This is reflected in the long-term decline of metals prices over the twentieth century. Why should this fact not be used as a basis for estimating future production costs?

The connection between depletion and costs is not at all certain and definitely not for the period 2000-2013. This

\footnotetext{
${ }_{3}^{3}$ This does not mean that attempts to draw up long run supply curves could not be useful for other purposes.
}

period covered the greatest commodities boom of recent times and one which, unquestionably, saw high levels of cost inflation associated with cyclical increases in labour, energy and supplies. It is a well-known fact (Crowson 2011b) that at higher prices, mining companies focus on production volumes rather than costs as any new unit of production will yield additional profits. Further, during such periods, mining companies tend to use parts of their mines with lower grades in order to extend the life of mine with material that would be impossible to mine at lower prices. Since 2013, operating costs of most mining operations around the world have fallen steeply (SNL 2017). For these reasons, the cost increases from 2000 to 2013 are most probably not a depletion phenomenon.

The methods chosen by Vieira et al. (2016) and Vieira et al. (2017) are based on industry costs of production and ore requirements, respectively, which are hard to measure and collect, and difficult to compare or project. In projecting costs or ore requirements, what one is effectively doing is projecting forward assumptions about how all the individual components of mining costs will develop in the future, which is to say, labour, energy and supplies as well as the residual impacts of depletion and technology. No one is that smart. It is for this reason that analysts of long-term cost trends have often resorted to the use of long-term prices on the not unreasonable basis that in competitive markets (which minerals markets generally are), prices will reflect the marginal costs of production. The data used by Vieira et al. (2016) are taken from World Mine Cost Data Exchange. ${ }^{4}$ These data, like all cost data, suffer from some serious flaws:

- They are modelled, not actual, data and, as such, are estimates which are not possible to check or evaluate. Hence, for example, site-specific solutions, methods, or prices of inputs are not captured.

- They cover only a part of the world production, i.e. what is produced in what used to be called the 'Western world'.5 What is known of the production costs in the rest of the world, which for all metals in the study, except copper and silver, account for more than $40 \%$ of total world production? For all metals, except iron ore, the share of production originating in the non- 'Western world' is furthermore increasing. The relevance of mines in the 'Western world' is hence getting smaller and smaller. See Table 1.

- The cost data might be comparable during 1 year, when they were established, but their absolute levels are not exact, and in particular not constant over time.

- Cost curves for by-product metals such as silver are not meaningful as the output is determined by supply and demand for other metals.

\footnotetext{
${ }^{4}$ These specific data are no longer available, but the discussion below is applicable to all cost data.

${ }^{5}$ See footnote to Table 1 for explanation to countries included.
} 
Table 1 'Non-Western' world share of global mine production 1995$2015(\%)$

\begin{tabular}{lcrrrr}
\hline & 1995 & 2000 & 2005 & 2010 & 2015 \\
\hline Copper & 37.6 & 28.2 & 24.0 & 20.9 & 21.1 \\
Gold & 34.9 & 33.2 & 27.7 & 25.2 & 22.7 \\
Iron ore & 30.8 & 31.6 & 26.6 & 29.7 & 46.5 \\
Lead & 50.8 & 53.2 & 42.9 & 30.0 & 26.3 \\
Manganese ore & 10.2 & 8.8 & 13.5 & 15.6 & 12.8 \\
Molybdenum & 55.3 & 38.0 & 36.9 & 29.9 & 22.5 \\
Nickel & 30.9 & 32.7 & 31.6 & 25.9 & 26.2 \\
Silver & 36.4 & 39.3 & 32.3 & 23.5 & 18.2 \\
Uranium & 57.5 & 60.3 & 56.2 & 33.3 & n.a. \\
Zinc & 51.5 & 47.5 & 36.2 & 29.3 & 26.2 \\
\hline
\end{tabular}

From Raw Materials Data. Western world includes Europe (excluding former CIS countries), Japan, Australia, New Zealand, Canada and the USA

\section{What is known?}

Many of the assumptions of Vieira et al. $(2016,2017)$ and other proponents of so-called future efforts methods are difficult to verify and are counterfactual when looking at historical developments.

\section{Observed ore-grade declines}

Several authors (usually by mis-citing Tilton, 2003) have in recent years proposed - as Vieira et al. $(2016,2017)$ have done - that it is reasonable to assume that mine sites with lower costs are the first to be exploited.

While it may be possible to surmise something similar about a single cohort of operating mines at any given moment, new mines are, of course, built and operated in the meantime. As a general rule, the mines which are first found to be profitable are the first to be exploited and it is by no means clear that among the mines known at a specific time, the ones with lowest operating costs will be exploited first. There are many examples of the opposite when transport cost, political risks, legislation, etc. stop investments in known high-grade deposits. One recent example is the Simandou iron ore deposit in Guinea, which is one of the highest-grade iron ore deposits in the world but which remains undeveloped. The example of the Copper Rand mine in Canada put forward by Vieira et al. (2016) as evidence for their theory is perhaps rather an example of where closure costs (i.e. costs of rehabilitation, etc.) are so high that it is more attractive for the owners to keep the mine going (or at least to put it on 'care and maintenance' and restart when possible) rather than enact a definitive closure of the mine.

Where a decline in global average ore grade has been observed (e.g. for copper, gold, nickel, platinum group metals and zinc), these have invariably been observed in selected countries over particular periods of time. Annex 5 of the UNEP International Resource Panel's report on 'Environmental Risks and Challenges of Anthropogenic Metals Flows and Cycles' (2013) ${ }^{6}$ shows that the ore grade declines discussed have mostly been the result of economic factors such as demand for high volumes and improved technologies (in exploration, mining, processing, etc.). 'This has allowed the gradual lowering of cut-off grades, the grade at which it is economic to process ore, and a substantial expansion of annual global production' (UNEP 2013). This is even the case within existing mines where obviously the natural concentration of the metal in the rock has not changed, but the amount of that rock that can be economically mined and processed (instead of sending to rock dumps or tailings dams) has changed. The type of mineralisation is another important factor. Porphyry copper deposits are today by far the most important type of copper mineralisation. These deposits are typically of relatively low grade, and in the past, the high mining costs associated with mining them could exceed the revenues. When technology enabled mining costs to be reduced, copper porphyries could be profitably mined even as ore grades declined.

It can also be seen in Annex 5 of the UNEP (2013) report that even for these metals, ore grade decline has not been constant, being interspersed with periods of ore grade increase associated with a different set of economic circumstances. The graphs depict the situation in single jurisdictions based on already discovered and reported grades at that time. Recent statistical work by Priester et al. (2018) shows that there are considerable volumes of high-grade ores available, which are not exploited.

The longer-term decline observed in all regions can be partly explained by technological development allowing for a greater contribution to production from lower-grade porphyry copper ore types (SX-EW processing - see Fig. A5.1 (UNEP 2013)); a greater contribution to production from refractory gold ore types (cyanide leach processing); and a greater contribution to production from lateritic nickel ores (HPAL processing). The trends in uranium are due to exploration uncovering previously unknown higher-grade deposits.

UNEP's Figs. A5.6, A5.7 and A5.8 reflect the gradual depletion of individual mines over time - those data cannot be used to draw conclusions about the entire global resource. These will be affected by the circumstances and decisions described by Crowson (2011a), Mudd et al. (2013), Northey et al. (2018) and others.

The experience over the last couple of centuries has been that new discoveries or increases in economic reserves have caused long-term average ore grades to decline. As

\footnotetext{
${ }^{6}$ Can be accessed on https://www.unenvironment.org/resources/report/ environmental-risks-and-challenges-anthropogenic-metals-flows-and-cycles.
} 
technologies have changed, new economic reserves have been discovered and others extended to lower-grade zones resulting in declines in the average grade of ore that has been mined and processed (Rötzer and Schmidt 2018). The grade to volume relationship for individual porphyry copper deposits is exponential, which is also part of the reason why head grades are inversely related to the tonnage of ore mined (Crowson 2011a, Northey et al. 2018) and ore grade declines have been accompanied by large increases in identified reserves.

Mudd et al. (2013) give a reasonably good explanation of what drives changes in ore grade (and what does not). Yet, in our view, even Mudd et al. (2013) erroneously believed that by referring to reported Mineral Resources, rather than Mineral Reserves, they were successfully capturing the most likely amount of copper available to society 'for decades to come'. This is reflected in a few speculative statements like 'Based on current Australian Cu resources, it is highly unlikely that average ore grades will ever increase' Mudd et al. (2013). Reported measured, indicated and inferred resources are a tiny subset of what is extractable and ongoing exploration continues to reveal high-grade deposits with every period of high metal prices. Gavin Mudd (Mudd et al. 2015) has subsequently found that formal code-based (JORC or other) estimates massively underestimate the mineral resources of by-product metals.

Generally, a lot of the recent work on ore grades suffers from the fact that its scope is invariably limited to the known deposits at hand. So, while the data can be useful to compare different known deposits today, they do not provide any added information about long-term availability, because they do not incorporate any information about the as-yet undiscovered deposits that further investment in exploration will surely find (Drielsma et al. 2016). There is a fundamental problem with using a biased, limited sample (grades of deposits discovered by exploration geologists, drilled-out, described and reported) to conclude anything about the quality or quantity of the totality that remains in an extremely heterogeneous sampling space (the earth's crust). Consultants, government or industry would never accept such reasoning if they were investigating or cleaning up a contaminated site - the sampling challenge is basically the same.

\section{Observed ore-grade increases}

UNEP's Figs. A5.2, A5.3, A.5.4 and A5.5 demonstrate the point that there are also examples of ore grade increases. There are differences across regions and processed copper ore grades in Australia, processed nickel ore grades in Canada, and processed uranium grades in Canada all increased over the second half of last century. The grades of iron ore at mines in Australia and Brazil today are generally higher than those exploited in the 1960s when the US, Europe and the Soviet Union dominated global output.
When technology improves or demand growth exceeds supply growth, then a decline in mined ore grades is to be expected (West 2011; Northey et al. 2018). When supply capacity exceeds demand, mined ore grades can be expected to increase despite continued extraction. There is evidence that this happened in nickel mines during the period 2000-2013, in gold mines from 2014 to $2017^{7}$ and probably in copper mines over a similar time period. Tungsten miners provide two recent examples of increases in average ore grade by application of new X-ray technology to more efficiently sort ore from waste rock (Premier African Minerals Press 2015; Mosser and Robben 2014).

To conclude on ore grade trends, there will be periods of average ore grade decline for specific commodities in specific regions, but these arise for different reasons and are interspersed with periods of average ore grade increase depending on prevailing economic circumstances.

\section{Observed exploration performance}

From time to time, it becomes harder to find economically viable high-grade deposits. This is invariably for geopolitical or socio-political reasons - not enviro-geological reasons. For example, there was in the past some industry-wide concern that new high-grade copper deposits were not being found. In hindsight, this may have been due to large parts of the globe being relatively inaccessible because under the influence of the USSR (Humphreys 2015). It could have also been partly due to the competitive advantage of a handful of super-large incumbent mines (see Mudd et al. (2013) analysis of the current fleet of mines). However, once the USSR fell apart and demand from China picked up, the influence of the large incumbent mines diminished and some very significant copper deposits were discovered-including the Oyu Tolgoi deposit in Mongolia. Some decrease in exploration success has been attributed to a focus on brownfield exploration as well as the shift of major mining houses away from in-house exploration and more involvement of less experienced juniors in the field (Schodde 2015).

So far, there are no indications either that a future increase in production from underground mines is likely or necessary. Over the past 20 years, the share of open pit mining of total ore production has been relatively constant at around $85 \%$ (Ericsson and Löf 2013). In the previous period, there was a sharp decline in underground mining, as a series of new giant porphyry copper deposits were brought into operation. The belief that the depletion of deposits close to the surface would result in more underground operations is certainly widespread

\footnotetext{
7 "To conclude, 2014-2017 saw a shift to smaller throughput, higher grade [gold mine] operations which were easier to fund and bring to market. Lower gold prices have made lower grade, high tonnage deposits less attractive than less capital intensive, lower throughput, high grade projects." (Foy 2017)
} 
Fig. 2 Technological development during twentieth century

\section{Technological development during 20th century}

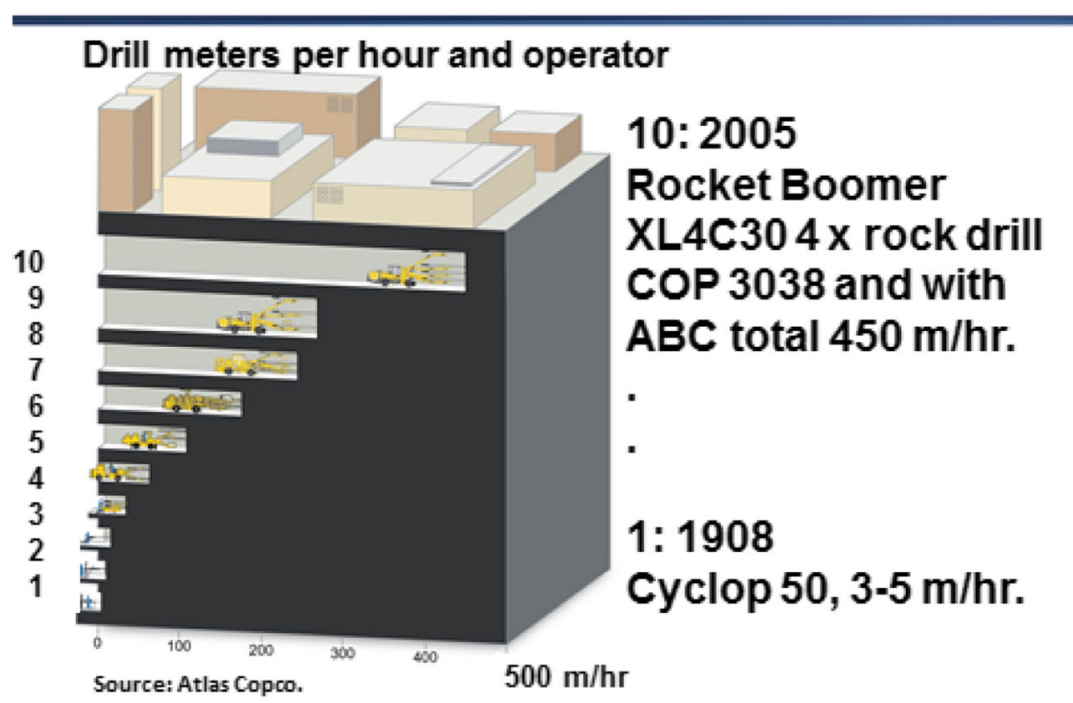

but not substantiated. The fact is that open pit mines get deeper, but the operating costs in open pit mines are still much lower than in underground mines. Modern and more effective mineral beneficiation processes lower production costs to such an extent that it is easier and more effective to locate an out-cropping copper deposit of $0.4 \%$ copper content than to find a deposit of a grade of $5 \%$ at a depth of $1 \mathrm{~km}$. It should further be noted that several of the most recent major copper discoveries were outcropping (Oyu Tolgoi, Pebble Creek, Sakatti) indicating that there is still a lot of surface exploration to do.

\section{Observed supply responses to high demand}

Several proposed LCIA methods, like the Type 3 future efforts methods (either as a precautionary measure or due to a lack of data), assume that technological development is held steady throughout the period of study, sometimes over 100 years.

During the twentieth century, it was technological developments that made increasing volumes of metal production possible, when prices were decreasing (see Schodde 2010). The assumption of an end of technological progress is also on a more philosophical level extremely pessimistic in that it assumes a complete stop to human ingenuity and drive to solve problems. Wellmer and Scholz (2017) usefully remind us that 'The normal innovation cycle in industry is about 15 years (Kernig 1998). It took 20 years to develop the technology for the exploitation of shale gas (Andruleit et al. 2011). For the petroleum industry in general, these lead times are estimated to be as long as 30 years (Roodhardt 2008). [...]. With the present reserve-to-consumption ratio of more than 300 , this means a duration of 10 innovation cycles. Who can overlook 10 innovation cycles?' Figure 2 gives an example of how drilling productivity has increased 100-fold during the past century.

\section{Observed production costs}

What does the cumulative supply function look like? Tilton (2003) has suggested that, as ore grades decline, a lot more material becomes geologically available. Moreover, because of productivity improvements in mining, production volumes can increase at these lower grades without production costs increasing significantly. In short, ore depletion does not necessarily imply cost increases at an industry level. By extension, prices, which in competitive markets must reflect trends in costs, are not therefore inevitably destined to rise.

Cost data going back deep into the past unfortunately do not exist. Price data, however, do. On the assumption that price trends will reflect underlying industry costs, the analysis of long-term prices can shed light what costs must have done. The trajectory of metals prices over time is an empirical matter and has been extensively researched. There is much scope in this research for debate over exactly what prices should be used, whether they are truly comparable over time, and what deflators should be applied to put them on a 'real', constant dollar basis. ${ }^{8}$ The results of such work naturally vary according to commodity, research methodology, and the time period employed. ${ }^{9}$ While there is no clear consensus around the view that real metal prices have declined over the longer-term, there is certainly no evidence which suggests that they have risen and no evidence whatsoever of prolonged price-induced scarcity. From this, it

\footnotetext{
$\overline{8 \text { e.g. Svedberg }}$ and Tilton (2003) The Real Real Price of Nonrenewable Resources: Copper 1870-2000, Institute for International Affairs, Stockholm University, Seminar Paper No: 723, 2003.

${ }^{9}$ Tilton (2003) pp53-55 and Appendix; Bilge Erten and José Antonio Ocampo (2012) Super-cycles of commodity prices since mid-nineteenth century, DESA Working Paper No 110; Jacks (2013) From boom to bust: a typology of real commodity prices in the long run, NBER Working Paper 18874.
} 
seems reasonable to infer that metal production costs have not risen over the long-term.

\section{What cannot be known}

So, there is no immutable law or relationship between extraction of metallic minerals and future ore grades. Ore grades decline or increase due to a complex set of economic conditions prevailing at any particular time, and there are no means of anticipating how long each of those time-frames will be. All data recently gathered by various authors can only tell us about what has happened so far-not what will happen in the future.

\section{Grades of new discoveries}

Several authors (usually by mis-citing Graedel et al. 2011) have in recent years proposed - as Vieira et al. (2016) have done - that it is reasonable to assume that $0.01 \%$ of the total metal content of the Earth's crust to a $3-\mathrm{km}$ depth will be ultimately available for human use.

There are no studies that solidly underpin this statement. Again, technological developments in the future might very well make deeper mining possible or a larger share than $0.01 \%$ of the total amount mineable. The availability of mineral deposits under the oceans is further not systematically studied at all. Seabed mining projects are far in their plans to mine the sea floor in the Pacific Ocean off the coast of PNG where sulphide crusts are to be exploited. These are interesting examples of geological processes, which are on-going today and not only in a geological distant past. They provide a link between the deeper layers of the earth and the crust not at all included in previous models of average grades, resources, etc.

Text Box: The concept of 'ore'

The elusive concept of 'ore' is often confusing. It must not be forgotten that 'ore' is an economic term and not an expression of metal content in the ground. It is simply not possible to make a statement on depletion based either on price fluctuation or on cost assessment, as prices, price expectations and cost (of both primary material and input factors such as mining equipment) interact and influence each other.

Waste rock results from mining, and tailings result from mineral processing. ${ }^{10}$ Overburden is often a different rock that is removed to access the ore-bearing rock before mining starts.

Both waste rock and tailings will be affected by the decided cut-off grade set by the mine manager. See figure below.

Figure. Some examples of different references to 'grade'

\begin{tabular}{|c|c|c|c|}
\hline Definition & $\begin{array}{l}\text { Ore grade } \\
\% \text { in the rock in situ }\end{array}$ & $\begin{array}{l}\text { Cut-off grade } \\
\% \text { required for profitable extraction }\end{array}$ & $\begin{array}{l}\text { Run-of-mine grade or head grade } \\
\% \text { in the ore sent for processing }\end{array}$ \\
\hline Type of Indicator & Observable environmental fact & Site-specific management standard & Observable performance metric \\
\hline Drivers of change in the indicator & Natural spatial variation & $\begin{array}{l}\text { Temporal variation due to changing } \\
\text { costs and prices }\end{array}$ & $\begin{array}{l}\text { Temporal variation due to } \Delta \text { ore grade } \\
+\Delta \text { cut-off grade }+\Delta \text { performance }\end{array}$ \\
\hline
\end{tabular}

From Drielsma 2014

Depending on forecast commodity prices and input costs, the mine will be designed to send a minimum grade of ore for processing (or directly as product) and the rest will be sent to waste rock dumps (even though it too contains lower grades of the value-mineral). Depending on the constraints of the processing plant and the requirements of the customer/market, the plant manager will have some limited capacity to set the process controls to produce a certain quality concentrate and therefore indirectly affect the quantity and characteristics of the tailings. Crowson (2011a, 2012) shows some evidence of mines processing higher grades when prices are low, and lower grades when prices are high.

There is no known correlation between new discoveries and ore grades. What is ore is not determined by grade alone but depends on selling price and production cost and is therefore assumed prior to mining and only really known for sure after mining. Phillip Crowson (2011a, 2012) shows that initial head grades (the percentage copper content of ore milled) of porphyry copper ore-bodies have stayed constant for the last 150 years.

What can be seen is a long-term trend of decreasing run-ofmine ore grades (i.e. the grades of material mined and processed) over time. Periods of decreasing ore grades in announced new mining projects over time have also occurred, but this data by definition excludes discoveries that were not developed into mining projects. A common rule-of-thumb within the industry is that 1 in every 1000 exploration projects results in a feasible mining project and 1 in every 10 such projects results in a mine.

A careful read of Graedel et al. (2011) reveals that those authors concluded that the Ultimate Recoverable Resource could not be reliably calculated for any metal.

\footnotetext{
$\overline{10}$ The word 'waste rock' gives associations to house hold waste, but it is important to understand that some waste rock and most often the 'overburden' is not environmentally harmful but inert or barren material.
} 


\section{Future investment conditions}

Some new discoveries have high and other low grades. Mining investment is inextricably linked to assumed future demand, infrastructure, logistics, etc. Maximising ore grade may result in production of insufficient volumes to satisfy customer demand or insufficient mine-life to satisfy the local community. So, at times, one might seek to maximise throughput (which will lower the average ore grade), or if trying to extend the designed mine-life, one may base feasibility studies on a lower assumed average ore grade. It is therefore quite possible that high-grade deposits are discovered, but not developed, before a lower-grade deposit elsewhere, which can provide higher volumes or incur lower transport costs. It is, for example, quite common for large established mines to mine ore that would be discarded as waste rock at other mines located in a more remote location.

The recent discovery of pure gold nuggets at surface across a large area in the West Australian Pilbara region by Canadian junior Novo Resources is but one example of new discoveries of high-grade deposits (Novo Resources 2017, 2018).

\section{Future processing decisions}

To be able to forecast mining costs, it would effectively be necessary to forecast all the contributing elements of mining costs: labour, power, depletion, technology, productivity, plus of course broader economic variables like inflation and exchange rates as well as political developments.

No doubt, more mining waste will have to be handled in the foreseeable future if the long-term economic prospects bring about the development of lower-grade deposits, or if the efficiency of existing mining and processing increases allowing cut-off grades to be lowered and more valuable metal(s) to be recovered from single deposits. Increased demand for typical by-products of base-metal mining might also cause some process flow sheets to be changed to produce more metals and more/different tailing streams. On the other hand, low commodity prices mean that investment in new capacity slows down and cut-off grades may to some extent increase, which theoretically means that marginally less tailings will be produced than in high-price periods. The same arguments hold for waste rock unless there is a higher contribution to global production coming from underground mines, which would tend to reduce waste rock volumes. Such a switch to underground mining is not happening, at least not yet as discussed above. Future economics and the changes brought by technology and policy development are in general impossible to predict.

\section{Future technologies}

Several studies characterise individual mineral deposits using a single average grade and a single tonnage derived from that single average grade. This masks quite a bit of real fluctuation or variation over time in the real world, as Mudd et al. (2013) allude to. This is because the 'discovered grade' (what really physically exists in the rock) is not the same as the 'cut-off grade' (what can and should be mined at a profit at any given time) or indeed the 'processed grade' (what is actually mined - either at a profit or a loss - at any given time). Depending on where you place the 'cut-off' grade, the total tonnage of a deposit will fluctuate over time (see also Schodde 2010). As technologies improve and cut-off grades decline, for many types of deposits, the total tonnage will increase (sometimes exponentially). If production costs stay constant, 'cut-off' and 'processed' grades are driven by commodity price. But, of course production costs rarely do stay constant. Mining technologies vary within commodities and within ore types, depending on economic feasibility at each particular location, but also mining processes change over time (also within individual mines) as technologies develop and get deployed through expansions and upgrades. It is necessary to be sceptical about how far it is possible to extrapolate any average figure for the range of technologies that are deployed now, let alone in the future.

\section{Conclusion}

Our conclusion from the discussion above is that mankind has been able to economically access ever-increasing amounts of material from often lower and lower-grade sources. What is impossible to conclude from this is that the environment no longer contains any of the higher-grade sources. In fact, all the available evidence suggests that higher-grade deposits are still out there (Johnson et al. 2014).

If prices rise, lower ore grades become economically minable, and if prices decrease, lower ore grades may no longer be mineable. The whole system is driven by demand so that high demand will also spur investment in exploration and development and the application of new technologies to allow supply of greater volumes at lower production costs. It is the difference between the production costs and long-term forecast prices that allows ore grades to decline and availability to increase. Eventually, as supply catches up, prices will again ease, but the technology will remain. So, finally there is a possibility that ore grades will decline while metal prices remain low. This is actually what happened in the 1990s and what some industry experts expect will now happen in the mid-2010s to 2020 s.

Vieira et al. (2016) conclude with a series of characterisation factors which, as measures of per unit surplus costs, are proposed as indicators of the future scarcity of the metals concerned. High on the list of those deemed scarce are the platinum group metals, platinum, palladium and rhodium, and low on the list are iron ore, lead and copper. What does 
this actually mean? In what way exactly is this a measure of scarcity? Is the suggestion here that the use of platinum group metals should be avoided, despite the fact that existing reserves are quite simply enormous (USGS PGM Commodity Summary 2017)? Scarcity surely has to be assessed in relation to demand for a metal. The characterisation factor for rhodium may be vastly higher than that for iron ore. But then, the demand for rhodium is only a very small fraction of that for iron ore. So, this cannot be a measure of relative scarcity, only absolute scarcity.

We are worried that whilst having all the appearance of sophistication, the Type 3 future efforts methodologies and results form a poor basis for policy development. The Vieira et al. $(2016,2017)$ papers are at best a theoretical exercise without credible long-term meaning. The fact is that the systems dealt with are complex and dynamic and they do not submit readily to modelling. For all the apparent sophistication of this approach, the outcome of this research - 'the characterisation factors' which are intended to be used as indicators of future scarcity and a factor in determining material choice - is spurious and no basis for sensible policy. Prices do not lie and contain far more information than what can ever be squeezed into an analytical model. We strongly oppose the use of any Type 3 future effort methods for use in Life Cycle Impact Assessment until the problems mentioned above and others outlined in the paper 'Mineral resources in life cycle impact assessment - defining a path forward' (Drielsma et al. 2016) are addressed. We remain critical optimists (Le 2017).

Open Access This article is distributed under the terms of the Creative Commons Attribution 4.0 International License (http:// creativecommons.org/licenses/by/4.0/), which permits unrestricted use, distribution, and reproduction in any medium, provided you give appropriate credit to the original author(s) and the source, provide a link to the Creative Commons license, and indicate if changes were made.

\section{References}

Barnett H (1979) Scarcity and Growth revisited. In: Smith VK (ed) In Scarcity and Growth Reconsidered. Johns Hopkins University Press for Resources for the Future, Baltimore, pp 163-217

Barnett H, Morse C (1963) Scarcity and growth: the economics of natural resource availability. Johns Hopkins University Press for Resources for the Future, Baltimore

Bilge Erten and José Antonio Ocampo (2012) Super-cycles of commodity prices since mid-nineteenth century, DESA Working Paper No 110

Bringezu S (2015) Possible target corridor for sustainable use of global material resources. Resources 4:25. https://doi.org/10.3390/ resources 4010025

Crowson P (2003) Mine size and the structure of costs. Resour Policy 29(1-2):15-36

Crowson P (2011a) Changes in copper yields and ore grades. Min J 2639
Crowson P (2011b) Economics of the minerals industry. In: Darling P (ed) SMEMining engineering handbook, 3rd edn. Society for Mining, Metallurgy, and Exploration, Inc

Crowson P (2012) Some observations on copper yields and ore grades. Resour Policy 37:59-72. https://doi.org/10.1016/j.resourpol.2011. 12.004

Dewulf J, Benini L, Mancini L, Sala S, Blegini GA, Ardetne F, Recchioni M, Pant R, Pennington D (2015) Rethinking the Area of Protection "Natural Resources" in Life Cycle Assessment. Environ Sci Technol 49:5310-5317

Drielsma JA (2014) Presentation at 55th LCA discussion forum-abiotic resources: new impact assessment approaches in view of resource efficiency and resource criticality. Managing Abiotic Resources How Mine Investment and Production Works. Accessed at https:// www.video.ethz.ch/events/lca/2014/spring/55th/a53ba3f9-76ba4ff8-8a25-0622cef31e6a.html. Accessed June 2018

Drielsma JA, Russell-Vaccari AJ, Drnek T, Brady T, Weihed P, Mistry M, Perez Simbor L (2016) Mineral resources in life cycle impact assessment - defining the path forward. Int J Life Cycle Assess 2016(21):85-105

Ericsson L, Löf A (2013) Mining \& Equipment Industry Seminar, vol 12. Handelsbanken, Stockholm, p 10

Foy R (2017) From core to pour; primary gold mine development and lead times 2010-2017. S\&P Global Metals and Mining Research: 04 September 2017, 17:33 GMT https://www.snl.com/interactivex/ article. aspx .KPLT $=7 \& \mathrm{id}=41852602$. Accessed June 2018

Goedkoop M, Heijungs R, de Schryver A et al (2013) ReCiPe 2008. A LCIA method which comprises harmonised category indicators at the midpoint and the endpoint level. Characterisation. Ministerie van VROM, Den Haag

Graedel et al (2011) Estimating long-run geological stocks of metals. UNEP International Panel on Sustainable Resource Management; Working Group on Geological Stocks of Metals. Working paper, June 11, 2011

Hotelling H (1931) The economics of exhaustible resources. J Polit Econ 39(2):137-175 The University of Chicago Press

Howie PA (2002) A study of mineral: Analysing long term behaviour and testing for non-competitive markets, Unpublished $\mathrm{PhD}$ dissertation, Colorado School of Mines, Golden, CO

Hubbert MK (1956) Nuclear energy and fossil fuels. Shell Development Company, Publication No 95

Humphreys D (2015) The remaking of the mining industry. Palgrave, Macmillan

ISO (2006) ISO 14044. Environmental management-life cycle assessment-requirements and guidelines. International Organization for Standardization, Geneva

Jacks, D S (2013) From boom to bust: a typology of real commodity prices in the long run, NBER Working Paper 18874

Johnson KM, Hammarstrom JM, Zientek ML, Dicken CL (2014) Estimate of undiscovered copper resources of the world, 2013: U.S. Geological Survey Fact Sheet 2014-3004, 3 p

Le KT (2017) Supply and exhaustion, Materials World June 2017

Manthy RS (1978) Natural resource commodities: a century of statistics. Resources for the Future, U.S.A.

Mosser A, Robben (2014) C. X-ray transmission-based ore sorting at the Mittersill tungsten mine, paper presented at the 27th IMPC Chile 2014

Mudd GM, Weng Z, Jowitt SM (2013) A detailed assessment of global $\mathrm{Cu}$ resource trends and endowments. Econ Geol 108:1163-1183

Mudd GM, Jowitt SM, Werner T, Weng Z (2015) Challenges in quantifying the conversion of mineral resources to production of byproduct and critical metals. European commission metal byproducts conference: exchange of good practices on metal byproducts recovery technology \& policy challenges, Brussels, 1213 November 
Nordhaus WD (1974) Resources as a constraint on growth. Am Econ Rev 64(1):22-26

Northey SA, Mudd GM, Werner TT (2018) Unresolved complexity in assessments of mineral resource depletion and availability. Nat Resour Res 27:241-255. https://doi.org/10.1007/s11053-017-9352-5

Novo Resources press releases (2017) Novo provides exploration update from Purdy's Reward (21 December 2017). http://www. novoresources.com/news-media/news/. Accessed June 2018

Novo Resources press releases (2018) First Comet Well bulk sample yields numerous gold nuggets (25 April 2018). http://www. novoresources.com/news-media/news/. Accessed June 2018

Premier African Minerals Press release 24 November 2015. http://www. premierafricanminerals.com/page.php?pID $=59 \& \mathrm{ppID}=6$. Accessed June 2018

Priester M, Dolega P, Ericsson M, Löf O (2018) Mineral grades: an important indicator for environmental impact of mineral exploitation. Min Econ in press. https://doi.org/10.1007/s13563-018-00168-x

Rötzer N, Schmidt M (2018) Decreasing metal ore grades - is the fear of resource depletion justified? Resources 7:88. https://doi.org/10. 3390/resources7040088

Schmidt-Bleek F Wieviel Umwelt braucht der Mensch? Faktor 10-das Maß für ökologisches Wirtschaften; Birkhäuser Verlag: Berlin, Germany, 1994 and The International Factor 10 Club's 2010 Declaration: a coalition of willing states needed to catalyse a tenfold leap in energy and resource efficiency in Proceedings of the Meeting of the Factor 10 Club, Carnoules, France, 9-12 September as cited in Bringezu, Stefan (2015) Possible Target Corridor for Sustainable Use of Global Material Resources. Resources 4:25. https://doi.org/10.3390/resources4010025;

Schodde R (2010) The key drivers behind resource growth: an analysis of the copper industry over the last 100 years. Available online: http:// www.minexconsulting.com/publications/Growth\%20Factors $\%$ 20 for\%Copper\%20SME-MEMS\%20March\%202010.pdf. Accessed 29 Jan 2016

Schodde R (2015) Exploration trends, finds and issues in Australia. Available online: http://www.minexconsulting.com/publications/ R\%20Schodde\%20Australia\%20Discovery\%20Performance\% 20-\%20IMARC\%20Nov\%202015\%20FINAL.pdf. Accessed 28 Jan 2016

SNL Metals \& Mining, cost database 2017

Sonderegger et al. (2017) Int J Life Cycle Assess. https://doi.org/10.1007/ s11367-017-1297-8;

Svedberg P, Tilton JE (2003) The real real Price of nonrenewable resources: copper 1870-2000, Institute for International Affairs, Stockholm University, Seminar Paper No: 723, 2003

Swart P, Dewulf J (2013) Quantifying the impacts of primary metal resource use in life cycle assessment based on recent mining data. Resour Conserv Recycl 73:180-187. https://doi.org/10.1016/j. resconrec.2013.02.007

Tilton JE (2003) On borrowed time? Assessing the threat of mineral depletion. Resources for the Future, Washington, pp 1-158

Tilton JE, Crowson PCF, DeYoung J Jr, Eggert GR, Ericsson M, Guzmán JI, Humphreys D, Lagos G, Maxwell P, Radetzki M, Singer DA, Wellmer F-W (2018) https://doi.org/10.1016/jmeradetaljerr

UNEP (2013) Environmental risks and challenges of anthropogenic metals flows and cycles, a report of the working group on the global metal flows to the international resource panel. In: Van der Voet E, Salminen R, Eckelman M, Mudd G, Norgate T, Hischier R (eds)

US Geological Survey, Mineral Commodity Summaries, Platinum-group metals, various years
Vieira MDM, Ponsioen TC, Goedkoop MJ, Huijbregts MAJ (2016) Surplus cost potential as a life cycle impact Indicator for metal extraction. Resources 5:2. https://doi.org/10.3390/ resources5010002

Vieira MDM, Ponsioen TC, Goedkoop MJ, Huijbregts MAJ (2017) Surplus ore potential as a scarcity indicator for resource extraction. J Ind Ecol 21:381-390. https://doi.org/10.1111/jiec.12444

Wellmer F-W, Scholz RW (2017) Peak minerals: what can we learn from the history of mineral economics and the cases of gold and phosphorus? Min Econ 30(2):73-93

West J (2011) Decreasing metal ore grades, are they really being driven by the depletion of high-grade deposits? J Ind Ecol 15(2):165-168

Annex: References for so-called Future Effort Assessment methods (in chronological order)

Müller-Wenk R (1998) Depletion of abiotic resources weighted on base of "virtual" impacts of lower grade deposits used in future. Institut für Wirtschaft und Ökologie, St. Gallen (IWÖ-Diskussionsbeitrag Nr. 57)

Steen B (1999) A systematic approach to environmental priority strategies in product development. CPM - Centre for Environmental Assessment of Products and Material Systems;

Goedkoop M, Spriensma R (2001) The eco-indicator 99 a damage oriented method for life cycle impact assessment-methodology report. Ministerie van VROM, Den Haag

Itsubo N, Sakagami M, Washida T, Kokubu K, Inaba A (2004) Weighting across safeguard subjects for LCIA through the application of conjoint analysis. Int J Life Cycle Assess 9:196-205. https://doi.org/10. 1007/BF02994194

Weidema BP, Hauschild MZ, Jolliet O (2007) Preparing characterisation methods for endpoint impact assessment. Available from lca-net. com/files/Stepwise2006v1.5.3.zip

Itsubo N, Inaba A (2012) Lime2. JLCA Newsl life-cycle assess Soc Japan 16 ;

Vieira MDM, Goedkoop MJ, Storm P, Huijbregts MAJ (2012) Ore grade decrease as life cycle impact indicator for metal scarcity: the case of copper. Environ Sci Technol 46:12772-12778. https://doi.org/10. 1021/es302721t

Goedkoop M, Heijungs R, de Schryver A et al (2013) ReCiPe 2008. A LCIA method which comprises harmonised category indicators at the midpoint and the endpoint level. Characterisation. Ministerie van VROM, Den Haag

Swart P, Dewulf J (2013) Quantifying the impacts of primary metal resource use in life cycle assessment based on recent mining data. Resour Conserv Recycl 73:180-187. https://doi.org/10.1016/j. resconrec.2013.02.007

Steen B (2015) The EPS 2015d impact assessment method-an overview;

Vieira MDM, Ponsioen TC, Goedkoop MJ, Huijbregts MAJ (2016) Surplus cost potential as a life cycle impact indicator for metal extraction. Resources 5:2. https://doi.org/10.3390/resources5010002

Vieira MDM, Ponsioen TC, Goedkoop MJ, Huijbregts MAJ (2017) Surplus ore potential as a scarcity indicator for resource extraction. J Ind Ecol 21:381-390. https://doi.org/10.1111/jiec.12444

Publisher's note Springer Nature remains neutral with regard to jurisdictional claims in published maps and institutional affiliations. 